\title{
NOTE
}

\section{Morphology of Philometroides barbi (Nematoda: Philometridae), a rare tissue parasite of the Mediterranean barbel Barbus meridionalis (Osteichthyes)}

\author{
František Moravec ${ }^{1, *}$, Andrea Šimková2 ${ }^{2}$ Martina Pečínková ${ }^{2}$ \\ Markéta Ondračková ${ }^{2,3}$ \\ ${ }^{1}$ Institute of Parasitology, Academy of Sciences of the Czech Republic, Branišovská 31, 37005 České Budějovice, \\ Czech Republic \\ ${ }^{2}$ Department of Zoology and Ecology, Faculty of Science, Masaryk Uuniversity, Kotlářská 2, 61137 Brno, Czech Republic \\ ${ }^{3}$ Institute of Vertebrate Biology, Academy of Sciences of the Czech Republic, Květná 8, 60365 Brno, Czech Republic
}

\begin{abstract}
A female specimen of the nematode Philometroides barbi Moravec, Šimková, Hanzelová, Špakulová et Cakić, 2005, a little-known histozoic parasite of the Mediterranean Barbus meridionalis, was recorded from the fin of its fish host in Bulgaria. Scanning electron microscopical examination, used for the first time in this species, made it possible to determine the character of cephalic papillae (14 papillae arranged in 2 circles) and amphids and confirmed the presence of 4 large caudal lobes. These features distinctly distinguish $P$. barbi from Philometroides cyprini and other congeners parasitizing European fishes.
\end{abstract}

KEY WORDS: Nematoda $\cdot$ Philometroides barbi $\cdot$ Barbus meridionalis $\cdot$ Bulgaria

\section{INTRODUCTION}

Philometroides barbi Moravec, Šimková, Hanzelová, Špakulová et Cakić, 2005 has only recently been established as the 6th species of philometrids parasitizing freshwater fishes in Europe and the third European member of Philometroides Yamaguti, 1935 (see Moravec et al. 2005). This specific, tissue-dwelling parasite of the Mediterranean barbel Barbus meridionalis Risso, 1827 has been described only on the basis of a single small subgravid female found in the host's fin in southern France, 2 small mature females (supposed to belong to this species) from the swimbladder in eastern Slovakia, and previously published inadequate data (Cakić et al. 2002) on the morphology of 3 large-sized subgravid females from the abdominal cavity of fish in Serbia, erroneously identified as Philometroides cyprini (Ishii, 1931) [syn. P. Iusiana (Vismanis, 1966)] (see Moravec et al. 2005). Because of the rare occurrence of $P$. barbi, its morphology remained insufficiently known.

\section{MATERIALS AND METHODS}

During parasitological examinations of fish from the Vidbol River (a small tributary of the Danube River) at Dunavci $\left(43^{\circ} 55^{\prime} \mathrm{N}, 22^{\circ} 50^{\prime} \mathrm{E}\right)$, a village near the town of Vidin, northwestern Bulgaria, 3 specimens of the Mediterranean barbel Barbus meridionalis (total body length 14 to $19 \mathrm{~cm}$ ) were examined on 11 July 2005. In one of them, a nongravid female of Philometroides barbi was found located in the fin. It was fixed in $70 \%$ ethanol. After examination under the light microscope, 
both body ends of the specimen were cut off, transferred to $4 \%$ formaldehyde solution, and used for scanning electron microscopy (SEM); the rest of body was used for DNA examination. The body ends were postfixed in $1 \%$ osmium tetroxide, dehydrated through a graded ethanol series, critical point dried and sputtercoated with gold; they were examined using a JEOL JSM-6300 scanning electron microscope at an accelerating voltage of $15 \mathrm{kV}$. Fish names follow Froese \& Pauly (2005).

\section{RESULTS AND DISCUSSION}

Although considerably smaller, the available nongravid female of Philometroides barbi was morphologically similar (Figs. 1 \& 2) to the conspecific subgravid female found in southern France (Moravec et al. 2005). The body length was $5.71 \mathrm{~mm}$ (as compared to $10.40 \mathrm{~mm}$ in the latter), with maximum width $163 \mu \mathrm{m}$. The cuticle was covered with numerous, irregularly distributed bosses. The oral aperture was oval, surrounded by 2 circles of cephalic papillae and a pair of large lateral amphids; the cephalic papillae of the outer circle were arranged in 4 submedian pairs (of which more lateral papillae were distinctly smaller), those of the inner circle were formed by 2 lateral and 4 submedian, very small single papillae. The oesophageal teeth appeared to be absent. The overall length of oesophagus was $993 \mu \mathrm{m}$, its maxi-

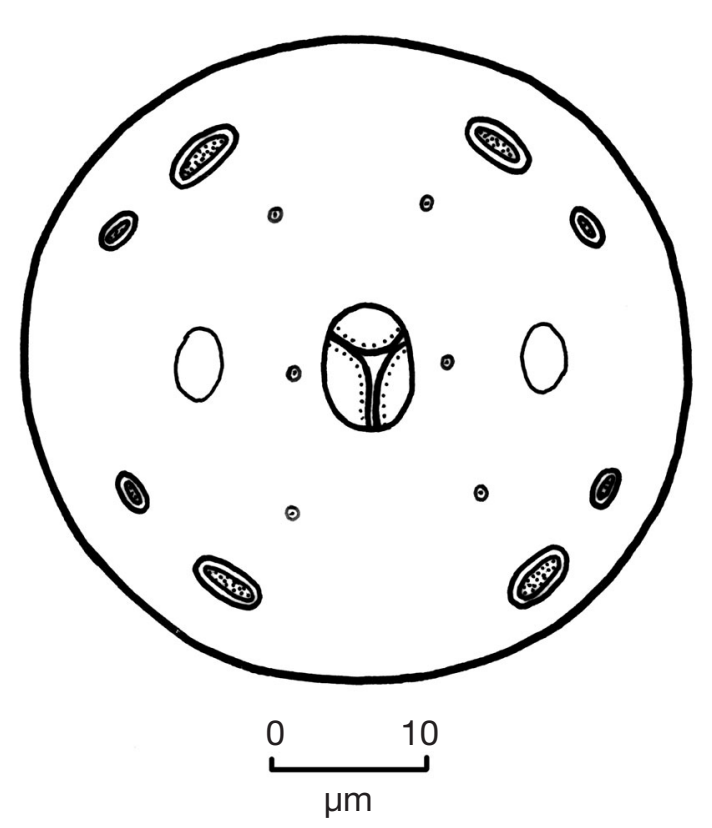

Fig. 1. Philometroides barbi Moravec, Šimková, Hanzelová, Špakulová et Cakić, 2005, cephalic end of subgravid female (apical view) mum width $78 \mu \mathrm{m}$; the size of its anterior bulb was $42 \times 42 \mu \mathrm{m}$, that of the ventriculus $15 \times 42 \mu \mathrm{m}$; the cell nucleus of the oesophageal gland was $598 \mu \mathrm{m}$ from the anterior extremity. The nerve ring was located $237 \mu \mathrm{m}$ from the anterior end of the body. Lateral caudal lobes were $30 \mu \mathrm{m}$ in length, sublateral caudal lobes $27 \mu \mathrm{m}$. The empty uterus extended nearly to the body end.

Philometroides barbi was not previously studied by SEM and, consequently, the present results provide the first data on the cephalic structures of this littleknown species. According to Moravec (2004), scanning electron microscopy is the only reliable method for the establishment of the exact number and distribution of otherwise hardly visible cephalic papillae in philometrids, which are considered to be an important taxonomic feature in this nematode group. The SEM study of the cephalic end of $P$. barbi shows that the pattern of the female cephalic papillae (8 larger papillae of the outer circle arranged in pairs and 6 small single papillae of the inner circle) is identical with that in many other species of Philometroides and Philometra Costa, 1845 (see Moravec 2004). However, the arrangement of the female cephalic papillae of Philometroides cyprini, a specific parasite of common carp Cyprinus carpio L., is different in that the papillae of the each external pair are fused together to form an elevated large cephalic lobe (Moravec \& Červinka 2005). The cephalic end of another palaearctic species of Philometroides, $P$. sanguineus (Rudolphi, 1819) from Carassius spp., has not yet been studied by SEM.

A characteristic feature of Philometroides barbi is the presence of 4 conspicuously large caudal lobes in larger females. Further studies on the morphology of this species are necessary, especially detailed descriptions of the hitherto unknown male and the gravid female with larvae. The present finding suggests that the preferred site of the larger females of $P$. barbi in the fish host is the subcutaneous tissue in fins, although they may also occur in the abdominal cavity, as observed by Cakić et al. (2002).

Philometroides barbi has so far been recorded from France, Slovakia and Serbia (Kašták 1956, 1957, Moravec et al. 2005), and now also from Bulgaria. Moravec et al. (2005) mention that the small mature females reported as Philometra abdominalis $[=P$. ovata (Zeder, 1803)] from Barbus meridionalis in Hungary by Molnár (1967) were probably also P. barbi. Taking into account the distribution area of $B$. meridionalis (from borders of France and Spain in the west to Romania, Ukraine and Poland in the east - see Froese \& Pauly 2005), it can be expected that $P$. barbi is distributed in suitable localities throughout the distribution area of its fish host. 


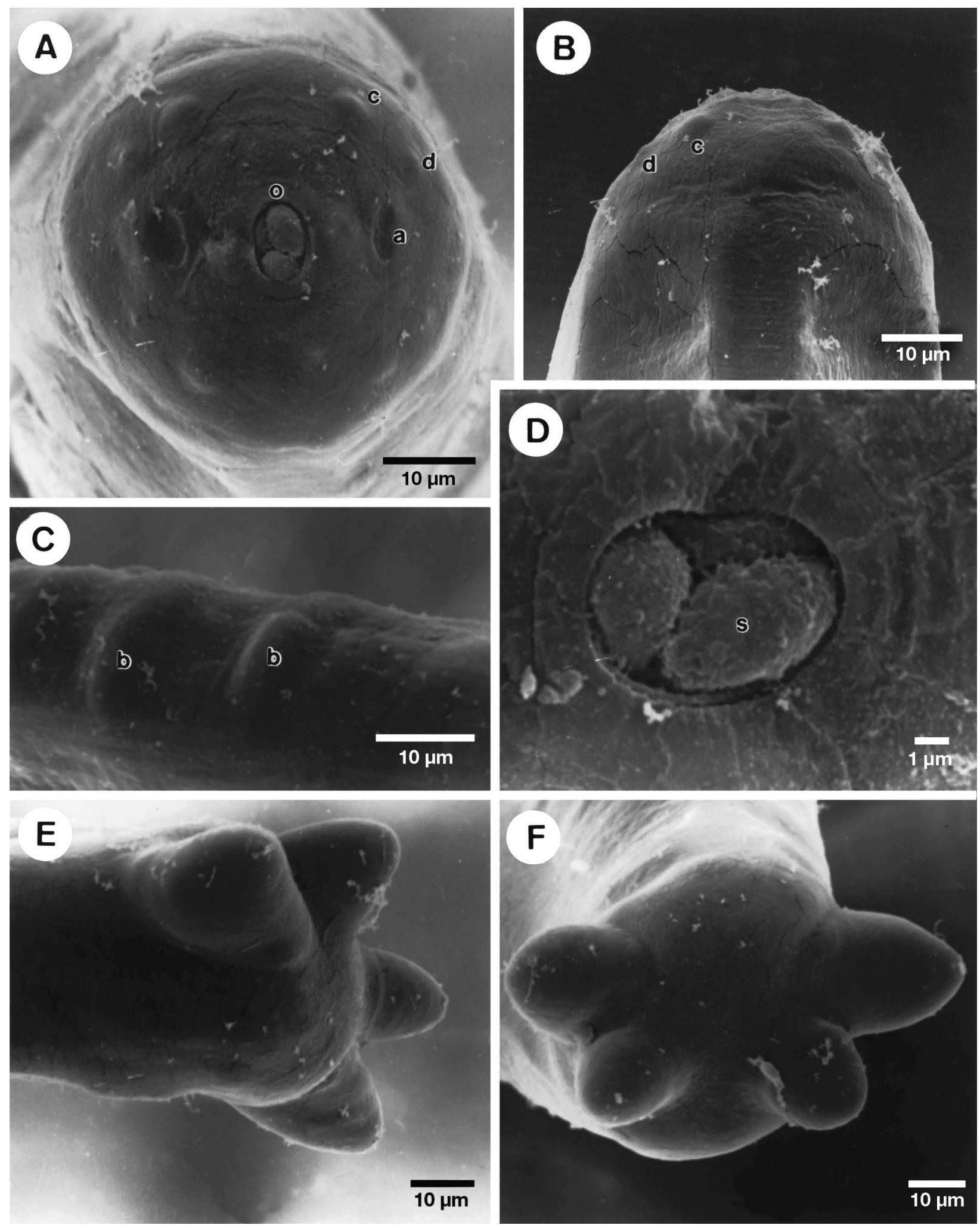

Fig. 2. Philometroides barbi Moravec et al. 2005, SEM micrographs of subgravid female. (A,B) Cephalic end, apical and lateral views respectively, (C) cuticular bosses, (D) region of oral aperture, apical view, (E,F) caudal end with large lobe-like projections, sublateral and apical views. Abbreviations: $\mathrm{a}=\mathrm{amphid}, \mathrm{b}=$ cuticular boss, $\mathrm{c}=$ larger cephalic papilla of outer circle, $\mathrm{d}=$ smaller cephalic papilla of outer circle, $\mathrm{o}=$ oral aperture, $\mathrm{s}=$ anterior end of oesophageal sector 
Acknowledgements. The authors thank Milen Vassilev, Jiří Huml and Matej Polačik for help with fish collection. The field study in Bulgaria was funded by the Ministry of Education, Youth and Sports of the Czech Republic (project no. LC522, Ichthyoparasitology Research Centre). AŠ, MP and MO were funded from the Research Project of the Masaryk University, Brno (no. MSM 0021622416). Thanks are also due to the staff of the Laboratory of Electron Microscopy of the Institute of Parasitology, ASCR, for their technical assistance and to Irena Husáková of the Department of Helminthology from the same institute for her help with the preparation of illustrations. This study was partly supported by the grant no. 524/03/0061 from the Grant Agency of the Czech Republic and the research project of the Institute of Parasitology, ASCR (no. Z60220518).

\section{LITERATURE CITED}

Cakić P, Stojanovski SS, Petrović Z, Lenhard M, Fister S (2002) The first record of parasite nematode genus Philometroides in Yugoslav freshwater fish. Exp Pathol Parasitol 5/8:3-6

Editorial responsibility: Wolfgang Körting,

Hannover, Germany
Froese R, Pauly D (eds) (2005) FishBase. World Wide Web electronic publication. www.fishbase.org, September 2005

Kašt'ák V (1956) Preliminary report on the finds of fish parasites in Slovak waters. Biológia, Bratislava, 11:624-635 (in Slovak)

Kašt'ák V (1957) Knowledge from the hitherto investigations into the helminth fauna of fishes in Slovak waters. Helminthologia 2:186-222 (in Slovak)

Molnár K (1967) Morphology and development of Philometra abdominalis Nybelin, 1928. Acta Vet Acad Sci Hung 17: 293-300

Moravec F (2004) Some aspects of the taxonomy and biology of dracunculoid nematodes parasitic in fishes: a review. Folia Parasitol 51:1-13

Moravec F, Červinka S (2005) Female morphology and systematic status of Philometroides cyprini (Nematoda: Philometridae), a parasite of carp. Dis Aquat Org 67: 105-109

Moravec F, Šimková A, Hanzelová V, Špakulová M, Cakić P (2005) Philometroides barbi sp. n. (Nematoda: Philometridae) from Barbus meridionalis, a new philometrid from European freshwater fish. Acta Parasitol 50:319-322

Submitted: October 18, 2005; Accepted: December 18, 2005 Proofs received from author(s): March 6, 2006 